\title{
Retraction Note: Dysregulation of cell cycle related genes and MicroRNAs distinguish the low- from high-risk of prostate cancer
}

Jiling Wen, Rongbing Li, Xiaofei Wen*, Guangming Chou, Jiasun Lu, Xuelei Wang and Yongchao Jin

\section{Retraction}

The Publisher and Editor regretfully retract this article [1] because the peer-review process was inappropriately influenced and compromised. As a result, the scientific integrity of the article cannot be guaranteed. A systematic and detailed investigation suggests that a third party was involved in supplying fabricated details of potential peer reviewers for a large number of manuscripts submitted to different journals. In accordance with recommendations from COPE we have retracted all affected published articles, including this one. It was not possible to determine beyond doubt that the authors of this particular article were aware of any third party attempts to manipulate peer review of their manuscript.

\section{Authors' information}

Jiling Wen and Rongbing Li are joint first authors.

Received: 3 March 2015 Accepted: 3 March 2015

Published online: 26 March 2015

\section{Reference}

1. Wen et al. Dysregulation of cell cycle related genes and microRNAs distinguish the low- from high-risk of prostate cancer. Diagn Pathol. 2013;9:156.

* Correspondence: xiaofwen@hotmail.com

Department of Urology, East Hospital, Tongji University School of Medicine, Jimo Road, Shanghai 200120, China

\section{Submit your next manuscript to BioMed Central} and take full advantage of:

- Convenient online submission

- Thorough peer review

- No space constraints or color figure charges

- Immediate publication on acceptance

- Inclusion in PubMed, CAS, Scopus and Google Scholar

- Research which is freely available for redistribution

Submit your manuscript at www.biomedcentral.com/submit
() Biomed Central

\section{() Biomed Central}

